\title{
Pengaruh Penambahan Petidin 0,25 mg/kgBB pada Bupivakain 0,25\% untuk Blok Infraorbital terhadap Lama Analgesia Pascabedah pada Operasi Labioplasti Anak
}

\author{
Anthon Vermana Ritonga, ${ }^{1}$ Ruli H. Sitanggang, ${ }^{2}$ Ezra Oktaliansah ${ }^{2}$ \\ ${ }^{1}$ Rumah Sakit Umum Daerah Sultan Taha Saefuddin Muara Kebo Jambi, \\ ${ }^{2}$ Departemen Anestesiologi dan Terapi Intensif Fakultas Kedokteran Universitas Padjadjaran RS \\ Dr. Hasan Sadikin Bandung
}

\begin{abstract}
Abstrak
Nyeri pascabedah labioplasti dapat dicegah dengan regional blok infraorbital bilateral. Bupivakain 0,25\% biasa digunakan untuk blok infraorbital dan penambahan petidin akan memperpanjang lama kerjanya. Penelitian telah dilakukan dengan uji klinis acak terkontrol tersamar tunggal terhadap 40 pasien ASA II usia 3 bulan-1 tahun yang menjalani operasi labioplasti di ruang operasi bedah sentral Rumah Sakit Dr. Hasan Sadikin Bandung pada Maret-Mei 2012. Setelah randomisasi secara blok permutasi, subjek dikelompokkan menjadi dua, yaitu 20 subjek menggunakan bupivakain $0,25 \% 1 \mathrm{~mL}$ pada tiap sisi (kelompok B) dan 20 subjek menggunakan kombinasi bupivakain $0,25 \%$ dan petidin $0,25 \mathrm{mg} / \mathrm{kgBB} 1 \mathrm{~mL}$ pada tiap sisi (kelompok BP) yang diberikan setelah induksi anestesi. Data tentang lama analgesi diuji dengan Mann-Whitney. Analisis statistik menunjukkan bahwa perbedaan lama analgesia antara kedua kelompok sangat bermakna $(\mathrm{p}<0,0001)$. Simpulan, peningkatan lama analgesia kombinasi bupivakain $0,25 \%$ dan petidin $0,25 \mathrm{mg} / \mathrm{kg}$ BB menghasilkan masa bebas nyeri sampai 36 jam, sedangkan pada bupivakain 0,25\% lebih singkat sekitar 18 jam. Tidak dijumpai efek samping dalam penelitian ini.
\end{abstract}

Kata kunci: Blok infraorbital, bupivakain, labioplasti, petidin

\section{Comparison Between the Addition of Pethidine $0.25 \mathrm{mg} / \mathrm{kgBW}$ in Bupivacain 0.25\% with Bupivacain 0.25\% for Infraorbital Blockade in Labioplasty Surgery in Children to the Length of Post Operative Analgesia}

\begin{abstract}
Labioplasty postoperative pain can be prevented by bilateral infraorbital regional block. Bupivacaine $0.25 \%$ is usually used in infraorbital block and pethidine as an adjuvant can prolong the postoperative analgesic. The research was a single-blind randomized clinical trial included 40 children ASA II aged 3 months-1 year underwent labioplasty surgery in central operating theatre Dr. Hasan Sadikin Hospital-Bandung during March-May 2012. After block of permutation randomization, the subjects were grouped into two, 20 subjects (group B) using bupivacaine $0.25 \% 1 \mathrm{~mL}$ on each side and 20 subjects (group of BP) using combination of pethidine bupivacaine $0.25 \%$ and $0.25 \mathrm{mg} / \mathrm{kgBW} 1 \mathrm{~mL}$ on each side after the induction of anesthesia. Measurement data of length of analgesia were tested with the Mann-Whitney Test. Statistical analysis showed that the difference of the length of analgesia between two groups analgesia was highly significant $(\mathrm{p}<0.0001)$. The conclusion of this study is that the increase of the length of analgesia in combination of bupivacaine $0.25 \%$ and pethidine $0.25 \mathrm{mg} / \mathrm{kgBW}$ produce pain-free period to 36 hours, whereas bupivacaine $0.25 \%$ is shorter, about 18 hours. The incidence of adverse effect was not found in this study.
\end{abstract}

Key words: Bupivacaine, infraorbital block, labioplasty, pethidine

Korespondensi: Anthon Vermana Ritonga, dr., SpAn, RS. Umum Daerah Sultan Taha Saefuddin, Jl. Lintas Kebo Bungo Km. 5, Muara Kebo, Jambi, mobile 082126306000, email anthon_vr@yahoo.com 


\section{Pendahuluan}

Penanganan nyeri pada anak adalah tantangan yangbesar. Metodepemecahan masalah dengan cara yang efektif hanya dapat dilakukan melalui pendekatan multidisiplin mencakup periode perioperatif. Masalah penanganan nyeri yang sering terjadi pada anak adalah penanganan nyeri pascabedah yang tidak adekuat sehingga meningkatkan morbiditas pascabedah, antara lain komplikasi pulmonal, penyembuhan yang menjadi lebih lama, serta dapat menyebabkan nyeri yang kronik. Penatalaksanaan nyeri yang adekuat membutuhkan beberapa aspek yang harus diperhatikan, antara lain evaluasi nyeri, pemilihan jenis, dan rute pemberian obat. ${ }^{1}$

Penilaian nyeri yang akurat membutuhkan metode penilaian nyeri yang tepat dan sesuai dengan usia anak. Penilaian intensitas, lokasi, dan kualitas nyeri pada anak yang lebih besar atau anak usia sekolah mungkin diungkapkan secara verbal, namun pada bayi dan anak yang belum dapat berbicara, metode evaluasi nyeri ini harus disesuaikan dengan kondisi tersebut. Parameter untuk penilaian nyeri pascabedah pada anak sangat bergantung pada faktor usia. Skala nyeri yang sering digunakan untuk anak yang belum dapat berbicara termasuk bayi adalah skor FLACC yang terdiri atas face, legs, activity, cry and consolability. ${ }^{2,3}$

Pembedahan bibir sumbing mengakibatkan nyeri pascabedah derajat sedang. Nyeri yang ditatalaksana secara adekuat meminimalkan kebutuhan oksigen, mengurangi beban kerja jantung dan pernapasan, serta mempercepat pemulihan. ${ }^{4}$

Blok saraf infraorbita bilateral adalah teknik analgesia lokal yang efektif apabila diberikan pada prosedur operasi bibir sumbing karena efek analgesia pascabedah yang adekuat tanpa risiko depresi pernapasan. ${ }^{5,6}$

Opioid adalah golongan obatstandar pilihan untuk penatalaksanaan nyeri dan merupakan analgetik poten yang tidak mempunyai ceiling effect. Petidin sering digunakan sebagai pilihan analgetik pada pasien yang menjalani bedah rawat jalan dan juga mendapatkan perhatian yang besar oleh karena memiliki efek depresi napas yang lebih rendah apabila dibandingkan dengan morfin. Pada satu penelitian dengan teknik intravenous regional anaesthesi (IVRA) dibuktikan bahwa petidin dengan konsentrasi rendah memiliki efek sebagai anestesi lokal pada saraf tepi. ${ }^{7}$

Efektivitas blok infraorbita untuk operasi bibir sumbing sudah lama terbukti tetapi hanya sedikit penelitian yang menggunakan opioid sebagai adjuvan untuk analgesia pascabedah. ${ }^{4}$ Suatu penelitian pada tahun 2007 terhadap 40 orang pasien usia 5-60 bulan yang menjalani operasi bibir sumbing pada kelompok yang mendapat blokade infraorbital dengan $1 \mathrm{~mL}$ bupivakain $0,25 \%$ pada setiap sisi didapatkan durasi analgesia mencapai 18 jam, sedangkan pada kelompok yang mendapat kombinasi 1 $\mathrm{mL}$ bupivakain $0,25 \%$ ditambah petidin 0,25 $\mathrm{mg} / \mathrm{kgBB}$ pada tiap sisi, lama durasi analgesia dapat mencapai 29 jam. Perbedaan durasi ini bermakna secara statistik $(\mathrm{p}=0,001) .{ }^{6}$

Opioid sebagai obat adjuvan blok saraf tepi terbukti memperpanjang lama kerja analgesia pascabedah dan opioid sintetik seperti petidin atau fentanil juga memiliki efek anestesi lokal. ${ }^{6}$

\section{Subjek dan Metode}

Penelitian ini bertujuan untuk menilai durasi analgesia pascabedah blok infraorbita dengan penambahan obat petidin $0,25 \mathrm{mg} / \mathrm{kgBB}$ pada bupivakain $0,25 \%$ bila dibandingkan dengan bupivakain $0,25 \%$ tunggal pada pasien anak yang menjalani prosedur operasi labioplasti dengan menggunakan skala nyeri FLACC.

Kriteria inklusi adalah anak-anak dengan diagnosis labioskizis yang menjalani operasi labioplasti yang terencana (elektif) di Rumah Sakit Dr. Hasan Sadikin Bandung pada periode Maret sampai Mei 2012, usia 3 bulan-1 tahun dengan status fisik ASA II, sedangkan kriteria eksklusi adalah dengan gangguan pembekuan darah (koagulopati), riwayat alergi terhadap obat yang digunakan dalam penelitian ini, dan juga terdapatkontraindikasi terhadap tindakan blok infraorbital. Kriteria pengeluaran yaitu perdarahan selama operasi yang memerlukan operasi ulang. 
Penelitian ini dilakukan secara prospektif dengan melakukan uji klinis acak terkontrol buta tunggal (doubleblind randomize controlled trial). Jumlah sampel ditentukan berdasarkan perbedaan antara dua rata-rata efektivitas dan dua tindakan, tingkat kepercayaan $(\alpha)$ 95\% serta besarnya uji kekuatan $(\beta) 95 \%$, sehingga didapatkan jumlah sampel sebanyak 18 orang untuk tiap kelompok, sehingga besar seluruh sampel minimal adalah 36.

Analisis statistik terhadap hasil penelitian menggunakan $t$-test tidak berpasangan apabila data adalah normal, dan alternatif Uji MannWhitney apabila data tidak normal, dan juga uji chi-kuadrat untuk data-data kategorik, dengan tingkat kepercayaan 95\% dan hasil dianggap bermakna bila $p<0,05$. Data disajikan dalam nilai rata-rata (mean) serta dianalisis dengan menggunakan program statistical product and service solution (SPSS) 17,0 for windows.

Randomisasi sampel memakai tabel blok permutasi ke dalam 2 kelompok perlakuan. Keduakelompokdiberikan premedikasidengan midazolam $0,5 \mathrm{mg} / \mathrm{kgBB}$ melalui oral 30 menit sebelum operasi. Dilakukan pemasangan alat monitor standar, lalu dicatat laju nadi, laju napas, dan juga saturasi preoperatif. Induksi anestesi dilakukan memakai sevofluran $8 \%$, oksigen $50 \%$, dan $\mathrm{N}_{2} \mathrm{O} 50 \%$ melalui sungkup, dan juga vekuronium $0,08 \mathrm{mg} / \mathrm{kgBB}$ intravena, kemudian diintubasi dengan pipa endotrakea. Pemeliharaan anestesi dilanjutkan memakai enfluran 2 hingga 2,5 volume \%, oksigen $40 \%$, dan $\mathrm{N}_{2} \mathrm{O} 60 \%$.
Tindakan aseptik dan antiseptik dilakukan dengan menggunakan larutan povidon iodin. Kelompok BP dilakukan blok saraf infraorbital menggunakan bupivakain 0,25\% sebanyak 1 $\mathrm{mL} / \mathrm{kgBB}$ ditambah dengan petidin $0,25 \mathrm{mg} /$ kgBB. Kelompok B dilakukan blok infraorbital memakai bupivakain 0,25\% sebanyak $1 \mathrm{~mL} /$ $\mathrm{kgBB}$. Setelah jarum masuk membentur tulang kemudian ditarik sejauh $\pm 1-2 \mathrm{~mm}$, dilakukan aspirasi sebelum dilakukan penyuntikan obat anestesi lokal sehingga memastikan tidak ada darah. Setelah penyuntikan dilakukan pijatan untuk meratakan obat di daerah penyuntikan selama 3 menit. Blok dianggap berjalan bila laju nadi tidak naik lebih dari $20 \%$ pada saat dilakukan penyayatan dibandingkan dengan laju nadi pada saat sebelum dilakukan blokade. Apabila terjadi kenaikan laju nadi lebih dari $20 \%$ pasien dikeluarkan dari penelitian.

Laju nadi, laju napas, serta saturasi oksigen diukur sesuai dengan prosedur tetap. Setelah operasi selesai pasien dibawa menuju ke ruang pemulihan. Pada saat pasien telah sadar penuh dilakukan penilaian nyeri pascabedah dengan menggunakan nilai FLACC 5 menit, 15 menit, 30 menit, 1 jam, dan setiap 1 jam selama 24 jam berikutnya.

\section{Hasil Penelitian}

Analisis data memperlihatkan semua variabel kedua kelompok sebelum tindakan blok saraf infraorbital tidak didapat perbedaan bermakna dalam hal karakteristik usia, berat badan, jenis

\section{Tabel 1 Nilai dan Simpang Baku Rata-rata Karakteristik Umum Subjek Penelitian pada} Tiap Kelompok

\begin{tabular}{lccc}
\hline \multirow{2}{*}{ Karakteristik } & \multicolumn{2}{c}{ Pemberian } & \\
\cline { 2 - 3 } & $\begin{array}{c}\text { B (n=20) } \\
\text { Mean (SD) }\end{array}$ & $\begin{array}{c}\text { BP (n=20) } \\
\text { Mean (SD) }\end{array}$ & Nilai p \\
\hline Usia (bulan) & $8,0 \pm 4,0$ & $7,0 \pm 3,4$ & $0,369^{*}$ \\
Berat badan (kg) & $7,5 \pm 1,7$ & $7,0 \pm 1,9$ & $0,362^{*}$ \\
Lama operasi (menit) & $98,5 \pm 7,3$ & $97,2 \pm 7,0$ & $0,587^{*}$ \\
Jenis kelamin & & & $1,000^{*}$ \\
$\quad$ Laki-laki & 7 & 7 & \\
Perempuan & 13 & 13 & \\
\hline
\end{tabular}

Keterangan: * Nilai p dihitung berdasarkan Uji Mann Whitney, chi-kuadrat $X^{2} ; \quad p>0,05=$ tidak bermakna 
kelamin, dan lama operasi ( $p>0,05)$ sehingga secara statistik subjek adalah homogen dan layak dibandingkan.
Seluruh subjek penelitian diobservasi dalam ruang pemulihan dan dilakukan penilaian skor nyeri FLACC setelah pasien sadar penuh.

Tabel 2 Perbandingan Nilai FLACC Pascaoperasi Kelompok Bupivakain 0,25 \% (B) dan Bupivakain 0,25\%+Petidin (BP)

\begin{tabular}{|c|c|c|c|c|c|c|}
\hline \multirow{2}{*}{ Waktu } & \multicolumn{5}{|c|}{ Nilai FLACC (B/BP) } & \multirow{2}{*}{ Nilai p } \\
\hline & $\mathbf{0}$ & 1 & 2 & 3 & 4 & \\
\hline T0 (5) & $20 / 20$ & - & - & - & - & - \\
\hline T1 (15) & $20 / 20$ & - & - & - & - & - \\
\hline T2 (30) & $20 / 20$ & - & - & - & - & - \\
\hline T3 (60) & $20 / 20$ & - & - & - & - & - \\
\hline T4 (120)-2 & $20 / 20$ & - & - & - & - & - \\
\hline T5 (180)-3 & $20 / 20$ & - & - & - & - & - \\
\hline T6 (240)-4 & $20 / 20$ & - & - & - & - & - \\
\hline T7 (300)-5 & $20 / 20$ & - & - & - & - & - \\
\hline T8 (360)-6 & $20 / 20$ & - & - & - & - & - \\
\hline Т 9(420)-7 & $20 / 20$ & - & - & - & - & - \\
\hline Т 10(480)-8 & $20 / 20$ & - & - & - & - & - \\
\hline Т $11(540)-9$ & $20 / 20$ & - & - & - & - & - \\
\hline T $12(600) 10$ & $20 / 20$ & - & - & - & - & - \\
\hline Т $13(660)-11$ & $20 / 20$ & - & - & - & - & - \\
\hline T $14(720) 12$ & $20 / 20$ & - & - & - & - & - \\
\hline Т 15 (780)-13 & 2020 & - & - & - & - & - \\
\hline Т $16(840)-14$ & $8 / 20$ & $12 / 0$ & - & - & - & $<0,0001^{*}$ \\
\hline Т 17 (900)-15 & $0 / 20$ & $19 / 0$ & $1 / 0$ & - & - & $<0,0001^{*}$ \\
\hline Т 18 (960)-16 & $0 / 20$ & - & $0 / 19$ & $1 / 0$ & - & $<0,0001^{*}$ \\
\hline T 19 (1020)-17 & $0 / 20$ & - & - & $20 / 0$ & - & $<0,0001^{*}$ \\
\hline Т 20 (1080)-18 & $0 / 20$ & - & - & - & $20 / 0$ & $<0,0001^{*}$ \\
\hline T 21 (1140)-19 & $0 / 20$ & - & - & - & $20 / 0$ & $<0,0001^{*}$ \\
\hline Т $22(1200)-20$ & $0 / 20$ & - & - & - & $20 / 0$ & $<0,0001^{*}$ \\
\hline Т 23 (1260)-21 & $0 / 20$ & - & - & - & $20 / 0$ & $<0,0001^{*}$ \\
\hline Т 24 (1320)-22 & $0 / 20$ & - & - & - & $20 / 0$ & $<0,0001^{*}$ \\
\hline Т 25 (1380)-23 & $0 / 20$ & - & - & - & $20 / 0$ & $<0,0001^{*}$ \\
\hline Т $26(1440)-24$ & $0 / 20$ & - & - & - & $20 / 0$ & $<0,0001^{*}$ \\
\hline Т 27(1500)-25 & $0 / 20$ & - & - & - & $20 / 0$ & $<0,0001^{*}$ \\
\hline Т 28 (1560)-26 & $0 / 20$ & - & - & - & $20 / 0$ & $<0,0001^{*}$ \\
\hline Т 29 (1620)-27 & $0 / 20$ & - & - & - & $20 / 0$ & $<0,0001^{*}$ \\
\hline Т 30 (1680)-28 & $0 / 20$ & - & - & - & $20 / 0$ & $<0,0001^{*}$ \\
\hline Т 31 (1740)-29 & $0 / 20$ & - & - & - & $20 / 0$ & $<0,0001^{*}$ \\
\hline Т 32 (1800)30 & $0 / 20$ & - & - & - & $20 / 0$ & $<0,0001^{*}$ \\
\hline Т 33 (1860)-31 & $0 / 20$ & - & - & - & $20 / 0$ & $<0,0001^{*}$ \\
\hline Т 34 (1920)-32 & $0 / 7$ & $0 / 13$ & - & - & $20 / 0$ & $<0,0001^{*}$ \\
\hline Т 35 (1980)-33 & - & $0 / 14$ & $0 / 6$ & - & $20 / 0$ & $<0,0001^{*}$ \\
\hline T 36 (2040)-34 & - & - & $0 / 14$ & $0 / 6$ & $20 / 0$ & $<0,0001^{*}$ \\
\hline Т 37 (2100)-35 & - & - & - & $0 / 14$ & $20 / 6$ & $<0,0001^{*}$ \\
\hline Т $38(2160)-36$ & - & - & - & & $20 / 20$ & $<0,0001^{*}$ \\
\hline
\end{tabular}

Keterangan: Nilai p dihitung berdasarkan uji chi-kuadrat $\mathrm{X}^{2}$ 


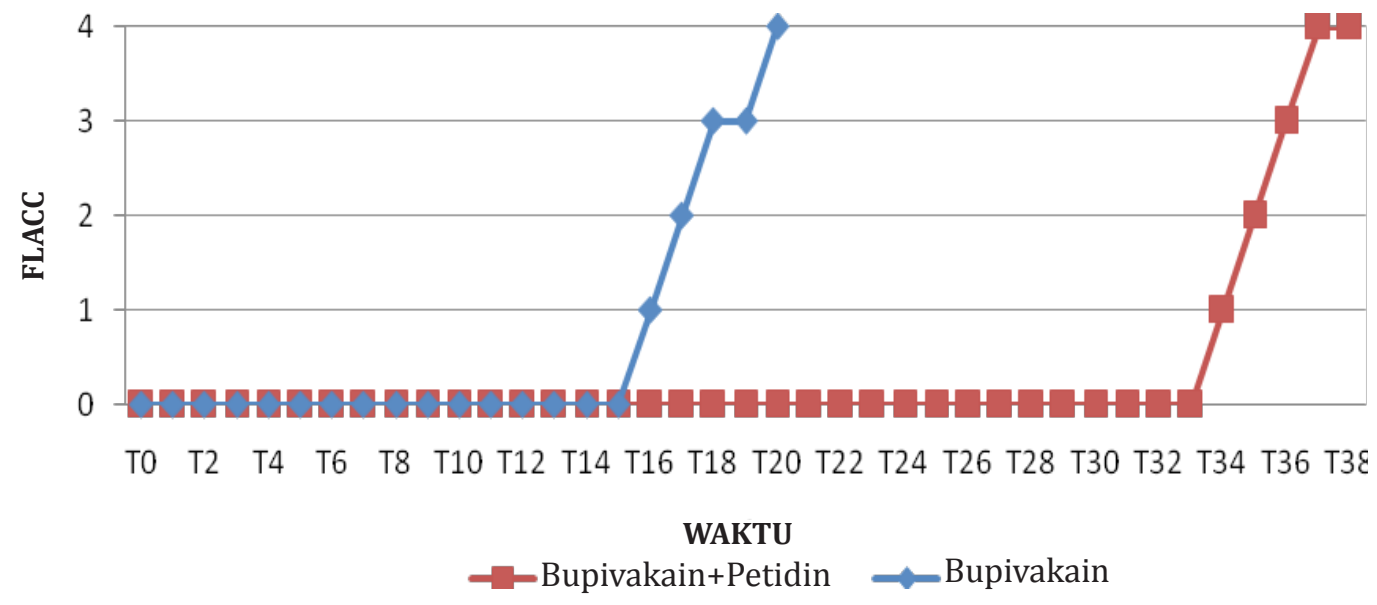

Gambar Hubungan Waktu terhadap FLACC pada Kelompok Penelitian Bupivakain dan Kelompok Bupivakain+Petidin (Nilai FLACC yang Dicapai pada Setiap Waktu)

Keterangan: T0=5 menit, T1=15 menit, T2=30 menit, T3-T38=setiap 60 menit

Terdapat 20 subjek penelitian kelompok B mendapat nilai FLACC $\geq 4$ yang mulai terjadi pada pengamatan di T-19 (18 jam), sedangkan pada kelompok BP nilai FLACC $\geq 4$ pertama kali terjadi pada pengamatan di T-36 (35 jam) yaitu sebanyak 6 subjek penelitian. Insidensi nyeri pascaoperasi (FLACC $\geq 4$ ) yang didapat pada kedua kelompok penelitian ini menunjukkan perbedaan bermakna dimulai dari T-15 hingga T-36 dengan nilai $\mathrm{p}<0,05$ (Gambar 1 ).

Pada kelompok bupivakain, nilai FLACC $=1$ dimulai pada T-16 yaitu pada menit ke-840 atau pada jam ke-14, sedangkan untuk kelompok bupivakain+petidin nilai FLACC=1 terjadi pada T-34 yaitu pada menit ke-1.920 atau pada jam ke-32. Hal ini menunjukkan bahwa perbedaan lama analgesia antara kedua kelompok sangat bermakna.

\section{Pembahasan}

Berdasarkan penelitian ini didapatkan bahwa anestesi regional dengan blokade infraorbital injeksi bilateral dapat memberikan analgesia yang adekuat dengan menggunakan anestetik lokal bupivakain 0,25\% menggunakan volume $1 \mathrm{~mL}$. Penelitian ini membuktikan bahwa blok analgesia pada operasi labioplasti memberikan analgesia mencapai 14 jam, sedangkan dengan penambahan petidin sebanyak $0,25 \mathrm{mg} / \mathrm{kgBB}$ maka lama analgesia akan meningkat hingga 32 jam. Hal ini sesuai dengan suatu penelitian yang membandingkan antara obat bupivakain 0,25\% $1 \mathrm{~mL}$ dan bupivakain 0,25\% $1 \mathrm{~mL}$ yang ditambah petidin $0,25 \mathrm{mg} / \mathrm{kgBB}$ pada blokade infraorbital untuk operasi labioplasti. Hal ini membuktikan penambahan petidin sebagai adjuvan pada anestesi lokal secara signifikan memperpanjang durasi analgesia. ${ }^{6}$

Penambahan obat adjuvan pada penelitian ini akan memperpanjang lama analgesia (Tabel 3). Pada kelompok blokade infraorbital yang mempergunakan kombinasi bupivakain 0,25\% dan petidin $0,25 \mathrm{mg} / \mathrm{kgBB}$ menunjukkan lama analgesia lebih panjang apabila dibandingkan dengan kelompok bupivakain $0,25 \%$, selama 1.920 menit (32 jam) berbanding dengan 840 menit (14 jam). ${ }^{6}$

Penggunaan opioid pada blok infraorbital pada pasien anak sering ditambahkan bersama dengan obat anestesi lokal yang bekerja secara sinergis. Opioid terdiri atas 2 (dua) golongan, yaitu hidrofilik dan lipofilik. Petidin (lipofilik) akan lebih terlokalisasi di daerah injeksi, onset kerja yang cepat, dan durasi yang lebih singkat apabila dibandingkan dengan morfin sebagai 
opioid hidrofilik. ${ }^{8,9}$

Reseptor opioid terdiri atas reseptor $\mu, \delta$, dan $\kappa$. Pemberian opioid di rongga infraorbital untuk penanganan nyeri akut dan nyeri kronik akan bekerja pada reseptor-reseptor opioid di perifer. Mekanisme analgesia opioid terjadi melalui cara blokade proses transmisi impuls nosiseptif di sistem saraf pusat serta jaringan perifer. Pada reseptor saraf presinaps, opioid akan menurunkan pelepasan neurotransmiter eksitasi saraf nosiseptif, terutama tipe C serta A delta. Reseptor pascasinaps yang ditempati opioid menyebabkan proses hiperpolarisasi yang akan mencegah pertukaran ion, keadaan tersebut akan menurunkan respons saraf saat mendapatkan rangsang nyeri setelah transmisi nosiseptif. ${ }^{10-12}$

Penggunaan teknik blok infraorbital yang dikombinasikan dengan anestesia umum telah digunakan dalam manajemen nyeri intra dan pascabedah bibir sumbing. Suatu penelitian pada tahun 2007 terhadap 40 orang pasien usia 5-60 bulan yang menjalani operasi labioplasti pada 2 (dua) kelompok penelitian. Kelompok pertama adalah kelompok B mendapat blok infraorbital memakai $1 \mathrm{~mL}$ bupivakain 0,25\% pada setiap sisi dan kelompok kedua adalah kelompok P mendapat $1 \mathrm{~mL}$ bupivakain 0,25\% ditambahkan petidin $0,25 \mathrm{mg} / \mathrm{kgBB}$. Durasi analgesia yang didapatkan adalah 18 jam pada grup B dan 29 jam pada grup P. Perbedaan durasi ini bermakna secara statistik $(p=0001) .{ }^{6}$

Penelitan pada tahun 2011 terhadap 45 orang anak berusia 5-60 bulan yang menjalani operasi labioplasti. Penderita dibagi menjadi 3 grup yang masing-masing terdiri atas 15 anak. Grup B mendapat blok infraorbital $0,75 \mathrm{~mL}$ bupivakain $0,25 \%$, grup $\mathrm{F}$ mendapat $0,75 \mathrm{~mL}$ bupivakain $0,25 \%$ dtambah fentanil $0,25 \mathrm{mcg} /$ kgBB, sedangkan grup $\mathrm{P}$ mendapat $0,75 \mathrm{~mL}$ bupivakain $0,25 \%$ ditambah petidin $0,25 \mathrm{mcg} /$ kgBB. Didapat durasi analgesia pada grup B 17,8 jam; grup F 25,53 jam; dan grup P 35,13 jam. ${ }^{4}$

Pada penelitian ini digunakan petidin 0,25 $\mathrm{mg} / \mathrm{kgBB}$ sebagai adjuvan bupivakain 0,25\% dengan volume $1 \mathrm{~mL}$, durasi analgesia yang diperoleh mencapai 2.100 menit atau 36 jam. Hal ini karena petidin mempunyai beberapa struktur menyerupai anestetik lokal golongan amin tersier yang lipofilik serta mempunyai karakteristik fisik serupa dengan obat anestesi lokal yang mempunyai daya larut cukup tinggi dalam lemak. Obat anestesi lokal menghambat konduksi impuls di dalam akson saraf perifer jika diberikan secara lokal dengan konsentrasi yang tinggi. Penelitian in vitro menunjukkan bahwa petidin ternyata memiliki efek seperti anestetik lokal apabila dihubungkan dengan kemampuannya dalam menghambat konduksi rangsangan saraf perifer atau akar akson pada bagian dorsal medula spinalis. ${ }^{13}$

Petidin juga bekerja melalui pembentukan ikatan bersama reseptor spesifik yang berada di dalam kanal natrium, sehingga menghalangi konduksi di dalam kanal natrium pada rentang konsentrasi yang sama dengan obat anestesi lokal, oleh karena itu dapat disimpulkan bahwa petidin bekerja pada tempat yang sama. ${ }^{14}$

Saat induksi serta pemeliharaan anestesi selama operasi berlangsung pada penelitian ini cukup dengan menggunakan campuran gas $\mathrm{O}_{2}, \mathrm{~N}_{2} \mathrm{O}$, dan volatil halotan. Pemasangan endotracheal tube (ETT) untuk patensi jalan napas memungkinkan dengan menggunakan obat pelemas otot yaitu vekuronium. Opioid intravena tidak digunakan dalam penelitian ini karena blokade infraorbital injeksi tunggal kombinasi bupivakain dengan petidin dosis rendah memberikan analgesia yang adekuat selama periode operasi dan pascabedah.

Pada penelitian ini tidak terjadi perubahan laju nadi, laju napas, dan tidak ada efek samping mual dan muntah setelah blokade infraorbital dilakukan. Perubahan laju nadi dan laju napas yang terjadi sesuai dengan peningkatan nilai FLACC yang mengindikasikan bahwa subjek mulai merasakan nyeri yang menandakan efek analgesia dari blokade infraorbital memakai obat anestesi lokal dengan adjuvan telah mulai menurun.

\section{Simpulan}

Simpulan penelitian ini bahwa lama analgesia blokade infraorbital injeksi tiap sisi dengan menggunakan kombinasi bupivakain 0,25\% dan petidin $0,25 \mathrm{mg} / \mathrm{kgBB}$ volume $1 \mathrm{~mL}$ lebih 
lama dibandingkan dengan bupivakain 0,25\% volume $1 \mathrm{~mL}$.

Kombinasi bupivakain 0,25\% dan petidin $0,25 \mathrm{mg} / \mathrm{kgBB}$ menghasilkan durasi analgesia yang lebih lama apabila dibandingkan dengan hanya bupivakain $0,25 \%$.

Perubahan hemodinamik akibatpenggunaan kombinasi obat tersebut tidak signifikan bahkan kejadian efek samping opioid seperti depresi pernapasan dan kemerahan pada kulit tidak ditemukan selama penelitian ini berlangsung.

\section{Daftar Pustaka}

1. Wu C. Postoperative pain and quality of recovery. Curr Opin Anaesthesiol. 2004;17(5):455-60.

2. O'rourke D. The measurement of pain in infants, children and adolesent: from policy to practice. Phys Ther. 2004;84:560-70.

3. Merkel S, Voepel-lewis T, Shayevitz J, Malviya S. The FLACC: a behavioral scale for scoring postoperative pain in young children. Pediatric Nursing. 1997;23(3): 293-7.

4. Mane R, Sanikop C, Dhulkhed V, Gupta T. Comparison of bupivacaine alone and in combination with fentanyl or pethidine for bilateral infraorbital nerve block for postoperative analgesia in paediatric patients for cleft lip repair: a prospective randomized double blind study. J Anaesth Clin Pharmacol. 2011;27(1):23-6.

5. Bosenberg A, Kimble F. Infraorbital nerve block in neonates for cleft lip repair: anatomical study and clinical application. Br J Anaesthesia. 1995;74:506-8.

6. Jonnavithula N, Durga P, Kulkarni D, Ramachandran G. Bilateral intra-oral, infra-orbital nerve block for postoperative analgesia following cleft lip repair in paediatric patients: comparison of bupivacaine vs bupivacaine-pethidine combination. Anaesthesia. 2007;62(6): 581-5.

7. Oldroyd G, Tham E, Power I. An investigation of the local anaesthetic effects of pethidine in volunteers. Anaesthesia. 1994;49:503-6.

8. Hogson P, Liu S. Local anesthetics. Dalam: Barash P, Cullen B, Stoelting R, penyunting. Clinical anesthesia. Edisi ke4. Philadelphia: Lippincott William and Wilkins; 2001. hlm. 449-65.

9. Morgan G, Michail M, Murray M. Clinical anesthesiology. Edisi ke-4. New York: McGraw-Hill; 2006.

10. Polaner D, Suresh S, Cote C. Regional anesthesia. Dalam: Cote C, Lerman J, Todres I, penyunting. A practice of anesthesia for infants and children. Edisi ke-4. Philadelphia: Saunders-Elsevier; 2009. hlm. 42.

11. Stein C, Clark JD, Oh U, Vasco MR, Wilcox GL, Overland AC, dkk. Peripheral mechanisms of pain and analgesia. Brain Res Rev. 2009;60(1):90-113.

12. Tambeli $\mathrm{CH}$, Fischer L, Parada CA. Opioid receptors. Dalam: Cairns BE, penyunting. Peripheral receptor targets for analgesia: novel approaches to pain management. Columbia: John Wiley \& Sons, Inc; 2009. hlm. 347-59.

13. Morgan G, Mikhail M, Murray M. Nonvolatile anesthesia. Dalam: Barash PG, Cullen BF, Stoelting RK, penyunting. Clinical anesthesia. Edisi ke-3. New York: McGraw-Hill; 2002. hlm. 192-7.

14. Wagner L, Eaton M, Sabnis S, Gingrich K. Meperidine and lidocain block of recombinant voltage-dependent $\mathrm{Na}$ channels. Anesthesiology. 1999;91:148190. 